\title{
The rediscovery of Frullania weberbaueri Steph.: The first record for Chile, its conservation status, and lectotypification
}

\section{El redescubrimiento de Frullania weberbaueri Steph., incluyendo su primer reporte para Chile, estado de conservación y lectotipificación}

\author{
Juan Larraín ${ }^{1 *}$, Reinaldo Vargas ${ }^{2}$, Jaime Uribe-M. ${ }^{3}$ \& Matt von Konrat ${ }^{4}$ \\ ${ }^{1}$ Instituto de Biología, Facultad de Ciencias, Pontificia Universidad Católica de Valparaíso, Campus Curauma, Av. Universidad \\ 330, Curauma, Valparaíso, Chile. \\ ${ }^{2}$ Herbario Federico Johow, Universidad Metropolitana de Ciencias de la Educación, Avda. José Pedro Alessandri 774, \\ 7760197, Chile. \\ ${ }^{3}$ Instituto de Ciencias Naturales, Universidad Nacional de Colombia, Bogotá, D.C. Apartado 7495, Bogotá, D.C., Colombia. \\ ${ }^{4}$ Science \& Education, The Field Museum, 1400 S Lake Shore Drive, Chicago, IL 60605, U.S.A. \\ *musgoschiloe@gmail.com
}

\begin{abstract}
We report the finding of a population of Frullania weberbaueri in Parque Nacional Pan de Azúcar, Antofagasta Province, Chile. This taxon was previously known only from the type specimen collected by August Weberbauer in Lima in 1901. The new gathering is fertile so we describe here its sexuality and perianths, together with the oil bodies and the habitat used by the species, and we provide a map of its known distribution. A lectotype for the name is here designated. This is the first record of a liverwort for the deserts of northern Chile, and the southernmost record for Frullania sect. Meteoriopsis.
\end{abstract}

KeYwords: Antofagasta, Atacama Desert, liverwort, Frullania sect. Meteoriopsis, "lomas” formations.

\section{RESUMEN}

Se reporta el hallazgo de una población de Frullania weberbaueri en el Parque Nacional Pan de Azúcar, Provincia de Antofagasta, Chile. Este taxón se conocía previamente sólo de la colección tipo realizada por August Weberbauer en Lima en 1901. La nueva colección está fértil, por lo que se describen aquí la sexualidad y los periantos, junto con los cuerpos oleosos y el hábitat utilizado por la especie, y se provee un mapa de su distribución conocida. Se designa un lectotipo para el nombre. Este es el primer registro de una hepática para los desiertos costeros del norte de Chile, y el registro más austral para Frullania sect. Meteoriopsis.

Palabras clave: Antofagasta, desierto de Atacama, hepática, Frullania sect. Meteoriopsis, formaciones de lomas.

\section{INTRODUCTION}

While doing fieldwork for the collection of lichens in the "lomas" formations of Pan de Azúcar National Park,

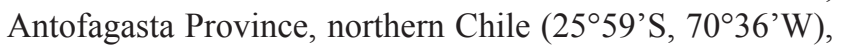
we came across a Frullania species growing as a pendent epiphyte on dead plant material on rock walls. It was immediately recognized as an interesting specimen since only a few bryophytes inhabit the "lomas" formations of northern Chile and Perú, and no Frullania species had previously been reported for northern Chile (Hässel de Menéndez \& Rubies 2009). The taxon was determined as the purportedly extremely rare taxon, $F$. weberbaueri $\mathrm{Steph}$.
It previously was known only from the type collection made in 1901 in the mountains of Lima, Peru, by the German botanist August Weberbauer. Frullania weberbaueri is treated in the monograph of $F$. subg. Meteoriopsis Spruce by Uribe Meléndez (2008). He mentioned a holotype although no specimen was explicitly mentioned in the original protologue (Stephani 1911: 510). Three duplicates of the collection number Weberbauer 27 were studied by Stephani and are available at G. Following the Articles 9.11 and 9.12 of the International Code of Nomenclature for algae fungi and plants (McNeill et al. 2012) a lectotype must be designated among the three existing duplicates. It is worth mentioning here that $F$. subg. Meteoriopsis sensu Uribe 
Meléndez (2008) is now regarded as F. (subg. Meteoriopsis) sect. Meteoriopsis (Spruce) Uribe, von Konrat \& Hentschel (Hentschel et al. 2015).

\section{MATERIALS AND METHODS}

Plants were collected in May 2009 in Pan de Azúcar National

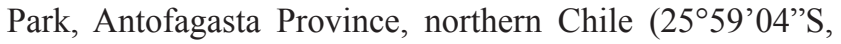
$70^{\circ} 36^{\prime} 54^{\prime \prime} \mathrm{W}$ ) at $730 \mathrm{~m}$ a.s.l. while doing lichen inventories. Nomenclature of initial branching appendages follow von Konrat \& Braggins (2001). For the production of microscopic images we used the same set up and protocols as described in Larraín et al. (2015).

\section{RESULTS}

Frullania weberbaueri Steph., Sp. Hepat. 4: 510. 1911. Type citation: Peruvia, Lima. [Lectotype (selected here): Frull. Weberbaueri St, Peru, Lima, in rupibus, Weberbauer No 27. 1901. Herbarium Genavense (G) G00066925!; Isolectotypes: G00066926!, G00066924!]. Figs. 1 and 2.

Although an extensive description of this taxon is provided by Uribe Meléndez (2008), the availability of fertile material allows to include some morphological aspects of this recent collection that improve the circumscription of the taxon and increase our understanding about its morphological variability. The following description is based in both the lectotype and the new gathering:

Plants up to $12 \mathrm{~cm}$ long, bi- to tri-pinnately branched, with branches up to $4.5 \mathrm{~cm}$ long and secondary branches up to $1.3 \mathrm{~cm}$ long and tertiary branches up to $2.5 \mathrm{~mm}$ long, $1.5 \mathrm{~mm}$ wide. Stems rounded in cross section, 120-150 $\mu \mathrm{m}$ wide, blackish in older parts becoming clear brown to hyaline in younger parts. Leaf lobes strongly convolute and clasping the stem when dry, extended when moist, wide-ovate, apiculate, sometimes terminating in a short mucro up to 3-4 cells long, slightly to clearly asymmetric, with large auricles either symmetric or asymmetric, not or slightly overlapped one over the other, margins entire to uneven, slightly recurved. Cells of leaf lobes 16-25 x 10$15 \mu \mathrm{m}$ at midleaf, quadrate to hexagonal and a little larger to the base where they reach $30-35 \times 20-25 \mu \mathrm{m}$, smaller and irregular in shape towards the apex, with somewhat equally thickened walls at base and midleaf, becoming strongly sinuose towards the apex, where trigones are conspicuous; cells at auricles oval to quadrate with equally thickened walls. Oil-bodies Bazzania type, rounded-oval to kidney-shaped, 5.0-9.5 x 3.0-4.8 $\mu \mathrm{m}$, appearing smooth, 2-4(5) per cell. Lobules parallel and disposed close to the stems, long cylindric, 260-450 x 75-120 $\mu \mathrm{m}$, with oblique mouth. Cells of lobules rectangular, with sinuose walls. Stylus reduced, erect, consisting of 3-6 uniseriate cells often with terminal slime papilla. Underleaves ovate-hastate, bifid for the distal 1/5-1/4 their length, with apiculate and acute segments, separated by a " $\mathrm{v}$ " shaped sinus, margins flat and entire, with long decurrent and undulated auricles, up to $290 \mu \mathrm{m}$ long, variable in shape, often ovate ended in a long apiculate, sharp projection. Branch appendages: first branch underleaves (BUL1) divided to base into a long ovate, tapering ventral segment, and dorsal saccate segment; first branch leaf-lobes (BL1) transformed into 2 saccate lobules, with stylus very long, to 11 cells long often with a terminal slime papilla. Dioicous. Androecia not seen. Gynoecia at the end of short branches 1-2 mm long located along the main stems or primary branches. Female bracts in two series, the innermost pair bifid and dentate, strongly concave, sheathing the perianth, with one segment larger than the other one, outermost pair similar to vegetative leaves, not concave, bearing a short lobule, border entire to uneven; inner bracteoles strongly dentate, bifid to half their length, outer bracteoles dentate too. Perianths subglobose, 0.8-1.2 mm long including beak, smooth, with three keels; beak relatively long, $90-120 \mu \mathrm{m}$ long, with tall papillae protruding the mouth. Sporophytes not seen.

Specimen examined: CHILE, Antofagasta Región, Antofagasta Province, Taltal, Pan de Azúcar National Park, Las Lomitas area, lat. $25^{\circ} 59^{\prime} 04^{\prime \prime} \mathrm{S}$, long. $70^{\circ} 36^{\prime} 54^{\prime \prime} \mathrm{W} \pm 4$ m (WGS 84), alt. ca. 729 m, epiphyte on plant detritus over rock, in vertical rock wall with soil accumulations, pendent, micro-exposition W. Leg. R. Vargas 2801, with D. Stanton. 10 May 2009 (COL, CONC, F).

\section{DISCUSSION}

Significantly, Uribe Meléndez (2008) remarked that Frullania weberbaueri was a very distinctive plant despite the fact it was only known from a single collection, and discussed the diagnostic characters that distinguished it morphologically from closely allied $F$. darwinii Gradst. \& Uribe from the Galápagos Islands, and $F$. phalangiflora Steph. from the tropical Andes. Frullania weberbaueri is easily separated from the latter two species by the underleaves with flat margins, acute segments, and long decurrent auricles, usually terminated in a sharp and long acumen. The symmetry of the base of leaves, one of the characters indicated by Uribe Meléndez (2008) as diagnostic in distinguishing between $F$. phalangiflora and $F$. weberbaueri, is variable in the new specimens observed, where some leaves are perfectly symmetric at the base whereas others are clearly asymmetric. However, these two taxa can be easily separated by the underleaf traits, as indicated above. The perianths are very similar in both species, although in $F$. phalangiflora they are more globose than in $F$. weberbaueri.

Uribe Meléndez (2008) treatise strongly focused on the morphology and did not give further information about the 

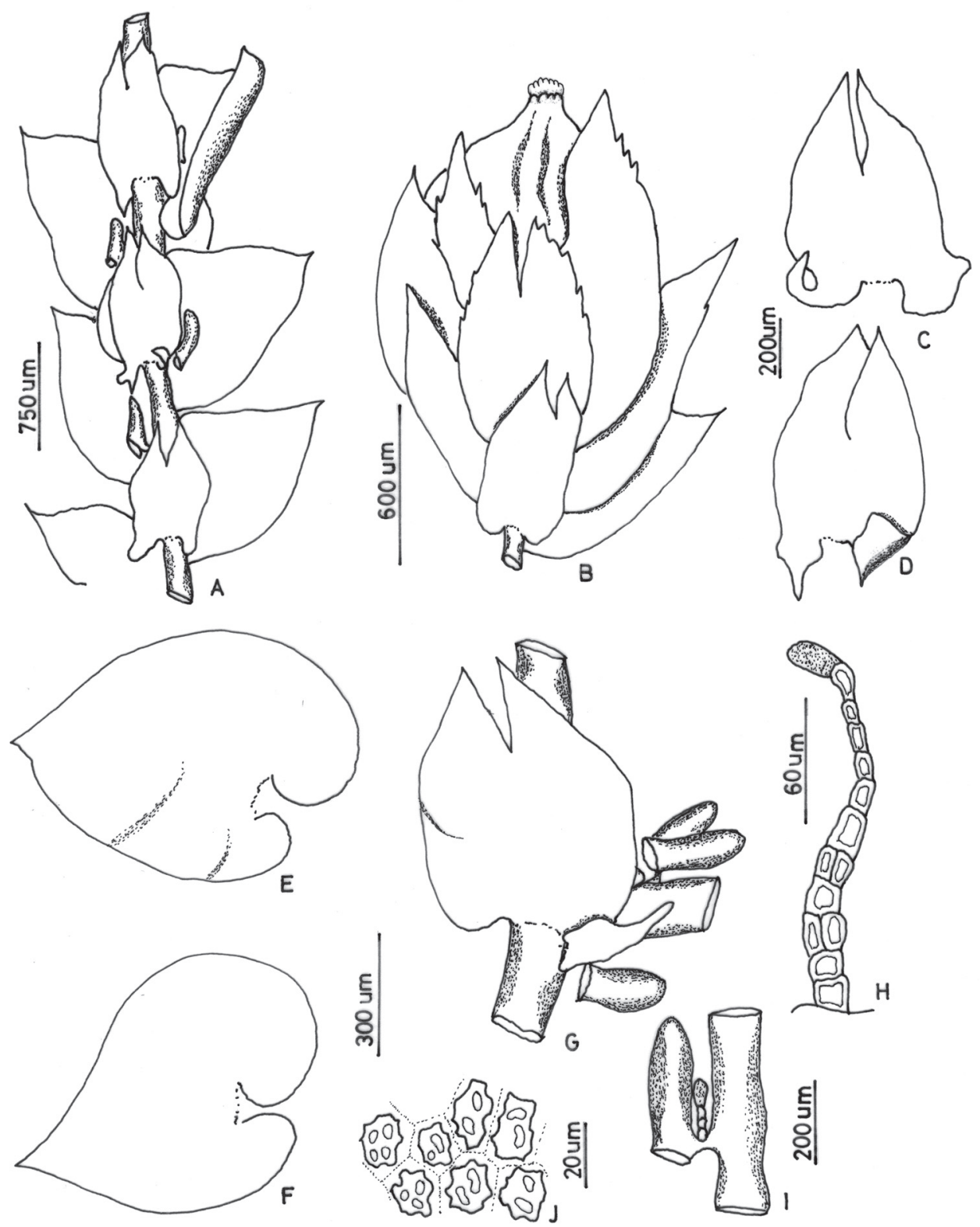

Figure 1. Frullania weberbaueri Steph. A. Habit wet, ventral view. B. Perianth surrounded by bracts. C-D. Underleaves. E-F. Leaf lobes. G. Underleaf on main stem showing double lobules of the first branch leaf lobe (BL1). H. Stylus of first branch appendages. I. Branch lobule and stylus. J. Oil-bodies at midleaf. (All from Vargas 2801 at COL).

Figura 1. Frullania weberbaueri Steph. A. Hábito en húmedo, vista ventral. B. Perianto rodeado por brácteas. C-D. Anfigastros. E-F. Lobos de las hojas. G. Anfigastro en tallo principal mostrando lóbulos dobles del primer lobo de las ramas (BL1). H. Estilo en los apendices de primera rama. I. Lóbulo y estilo de una rama. J. Cuerpos oleosos en la hoja media. (Todos de Vargas 2801 en COL).

locality details of the type specimen of $F$. weberbaueri both because the scanty information provided by Stephani (1911) and the poor label information of type material. Species of F. sect. Meteoriopsis grow in high Andean forests, between 1100 and $3800 \mathrm{~m}$ a.s.l., with the sole exception of the populations of the Galapagos Islands, where the four taxa occurring there can be found between 300 and $700 \mathrm{~m}$ a.s.l. (Uribe Meléndez 2008). Noteworthy, F. weberbaueri would be the only taxon of the group, together with $F$. darwinii, restricted to the lowlands of arid or desertic zones (Fig. 3).

Although the information about the type collection of $F$. weberbaueri given both in the protologue and as annotated in the labels of the type collection is very vague, only indicating the general area (Lima) and the substrate ("in rupibus"), one of the isotypes at $\mathrm{G}$ has the annotation "Peru, Amankai bei Lima". It would make sense that 

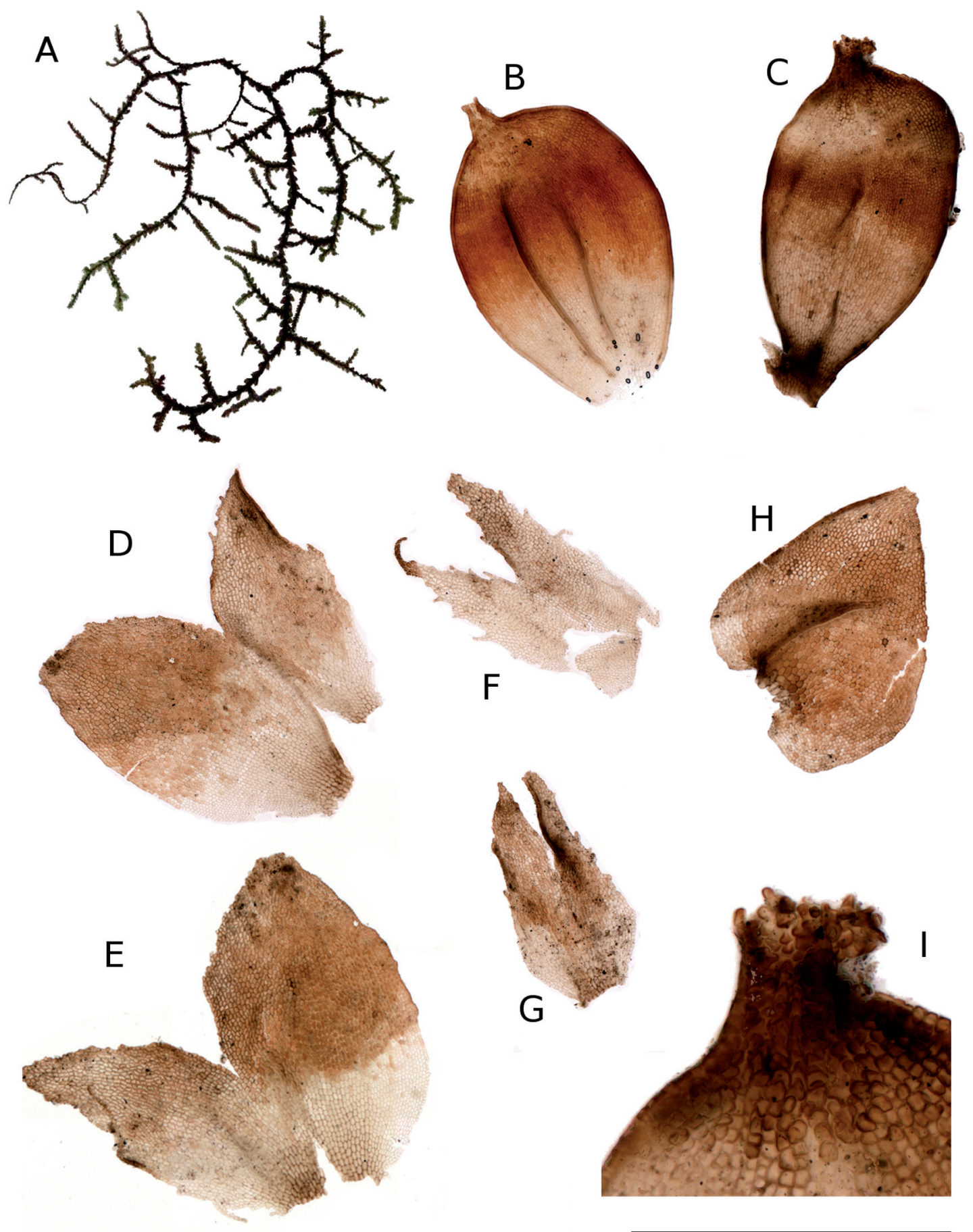

Figure 2. Frullania weberbaueri Steph. A. Habit wet, dorsal view, complete plant. B. Perianth, ventral view. C. Perianth, dorsal view. D-E. Inner bracts. F. Inner bracteole. G. Outer bracteole. H. One of the two outer bracts. I. Perianth mouth. (Scale: A= $50 \mathrm{~mm}$; B-H = $1 \mathrm{~mm}$; I $=300 \mu \mathrm{m}$; all from Vargas 2801 at F).

Figure 2. Frullania weberbaueri Steph. A. Hábito en húmedo, vista dorsal, planta completa. B. Perianto, vista ventral. C. Perianto, vista dorsal. D-E. Brácteas internas. F. Bracteola interna. G. Bracteola externa. H. Una de las dos brácteas externas. I. Boca del perianto. (Escala: $\mathrm{A}=50 \mathrm{~mm} ; \mathrm{B}-\mathrm{H}=1 \mathrm{~mm} ; \mathrm{I}=300 \mu \mathrm{m}$; todos de Vargas $2801 \mathrm{en} \mathrm{F}$ ). 
Weberbauer was referring to the Lomas de Amancaes, a low elevation hill range located in the heart of the city of Lima, separating the districts of Rímac, Independencia, and San Juan de Lurigancho, with altitudes between 300 and $800 \mathrm{~m}$ a.s.l. (Trinidad et al. 2012). The vegetation of this locality corresponds to the "lomas" formations, which are scattered vegetation islands located on a matrix of hyper-arid low coastal mountains (up to $1000 \mathrm{~m}$ a.s.l.) along the Peruvian and north Chilean desertic coasts between $6^{\circ} \mathrm{S}-30^{\circ} \mathrm{S}$ (Dillon 1997, Dillon \& Hoffmann 1997). In these formations fog accumulates during part of the year providing enough moisture for the development of a rich and particular vegetation, full of endemic species (Rundel et al. 1991, Dillon et al. 2003). The new collection of $F$. weberbaueri was made in the same kind of habitat, although further south and slightly different in terms of topography, climate and vegetation (Rundel et al. 1991). The area receives a strong influence of the coastal fog or "camanchaca" in the establishment and perpetuation of the plant community, mostly dominated by Euphorbia lactiflua Phil. and Eulychnia saint-pieana F.Ritter at the top of the coastal hills (ca. $800 \mathrm{~m}$ a.s.1., Rundel et al. 1996). Notwithstanding the rich plant community with ca. 207 vascular plants (Rundel et al. 1996), a quite rich lichen community develops using all available substrates. Associated species of $F$. weberbaueri at the collection site were the northern Chile and southern Peru coastal endemics Chrysothrix granulosa G.Thor. and Follmannia orthoclada (Zahlbr.) Frödén, Arup \& Søchting, and the Chilean endemics Roccellinastrum spongoideum Follmann (growing usually as an epiphyte on cacti spikes), Caloplaca rubina Zahlbr., Arthothelium halophilum Follmann, Dolichocarpus chilensis R.Sant., Pentagenella gracillima (Kremp.) Ertz \& Tehler, Pentagenella fragillima Darb., Buellia taltalensis C.W.Dodge, among others. There are almost 90 of these vegetation islands along the coast of northern Chile and Peru (Duncan \& Dillon 1991, Dillon 1997, Dillon \& Hoffmann 1997), and their bryophyte flora is virtually unknown. Although these are not species-rich habitats for bryophytes, they are clearly underrepresented in herbaria due to several reasons, including the small size and scarcity of the species that can survive in desertic areas, together with the fact that few bryologists visit these ecosystems, being bryophytes often ignored by flowering plant botanists or lichenologists.

This is the first liverwort ever recorded for the coastal desert of northern Chile, and the first one for the Antofagasta Region. Although Hässel de Menéndez \& Rubies (2009) did not mention a single liverwort species reported for Chile north of Coquimbo Region, there is a record for Plagiochasma rupestre (G.Forst.) Steph. var. rupestre from "Atacama", without exact locality (Bischler-Causse et al. 2005), based on a collection by Thomas Morong, who collected several flowering plants in the Atacama desert in 1890. The record of Lophocolea rectangularis Herzog from
"Nordchile: Fundo Siete Hermanos" (Herzog 1954: 43) is likely to refer to Fundo Siete Hermanas, near Viña del Mar in central Chile. There is a locality east of Copiapó, Atacama, called "cerro Siete Hermanos", but this is a place of high elevation and is very dry, and it is highly unlikely that this is the locality where the type of Lophocolea rectangularis was collected, since Herzog (1954) describes it as growing on bark together with Radula species. A recent contribution reports five new species of liverworts for Arica and Parinacota Region, although they were all collected in the high Andean plateau (Ardiles \& Fariña 2014).

Frullania weberbaueri was proposed by Uribe Meléndez (2008) to be classified as a vulnerable taxon, following the criterion D2 of the IUCN (2012). The record of this new population supports that assessment and so the species is proposed to be included as a vulnerable taxon for Chile as well (VU D2). These fragile ecosystems are threatened by multiple factors, including habitat size reduction due to urbanization, road construction, thermoelectric, industrial and urban pollution, goat grazing, erosion, commercial plant collecting, fuelwood collecting, among others (Dillon 1997, Dillon \& Hoffmann 1997, Trinidad et al. 2012), so efforts in conservation and more bryophyte sampling are urgent in order to know and catalogue their diversity before they disappear.

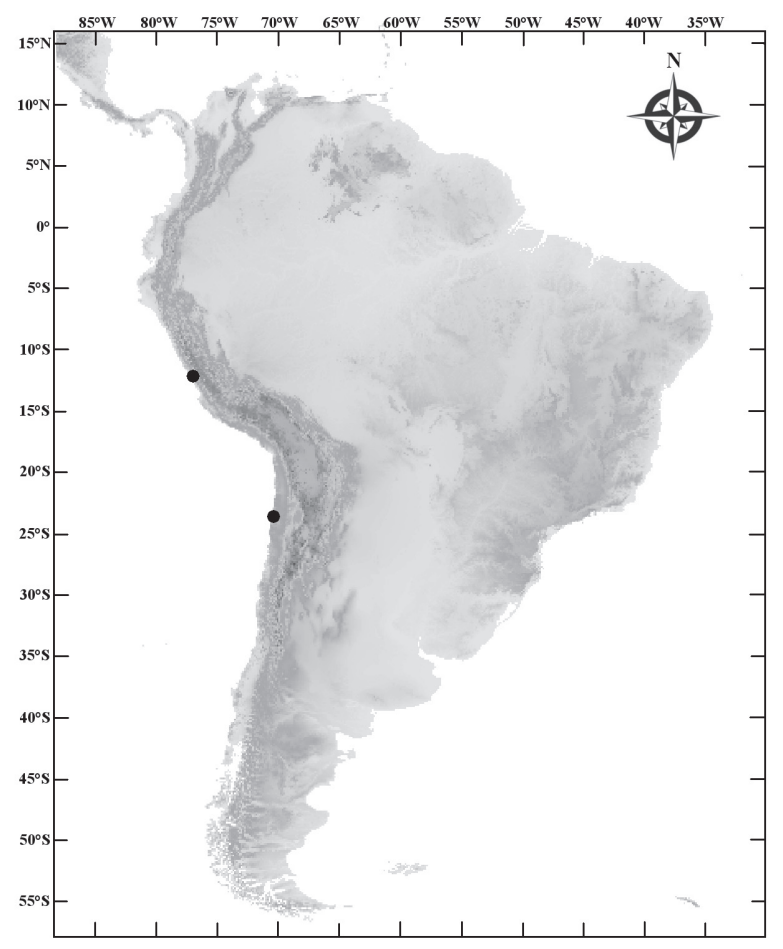

FIgURe 3. Frullania weberbaueri Steph. Distribution map.

FIgURA 3. Frullania weberbaueri Steph. Mapa de distribución. 


\section{ACKNOWLEDGEMENTS}

We would like to thank Dr D. Stanton (University of Minnesota-Twin Cities) for his help and companionship during the fieldwork, and Lauren Smith for taking the microscopic photographs with the equipment kindly funded by the Grainger Foundation. Special thanks are due to CONAF and their staff at Pan de Azúcar National Park for their logistic help and collecting permits. The fieldwork was partly supported by a CONICYT grant $\left(\mathrm{n}^{\circ} 24090066\right)$ and a MECESUP scholarship (UMC0204) given to RV.

\section{REFERENCES}

Ardiles, V. \& M. FariÑa. 2014. Flora no vascular de la Región de Arica y Parinacota, Chile: nuevos registros y consideraciones biogeográficas. Boletín del Museo Nacional de Historia Natural, Santiago, Chile, 63: 213223.

Bischler-Causse, H., S.R. Gradstein, S. Jovet-Ast, D.G. Long \& N. Salazar Allen. 2005. Marchantiidae. Flora Neotropica, Monograph 97.

Dillon, M.O. 1997. Lomas formations-Peru. In: S.D. Davis, V. H. Heywood, O. Herrera-McBryde, J. Villa-Lobos \& A.C. Hamilton (eds.), Centres of Plant Diversity, A Guide and Strategy for their Conservation, pp. 519-527. WWF, Information Press, Oxford.

Dillon, M. \& A. Hoffmann. 1997. Lomas formations of the Atacama Desert, northern Chile. In: S.D. Davis, V. H. Heywood, O. Herrera-McBryde, J. Villa-Lobos \& A.C. Hamilton (eds.), Centres of Plant Diversity, A Guide and Strategy for their Conservation, pp. 528-535. WWF, Information Press, Oxford.

Dillon M., M. NaKawaka \& S. Leiva. 2003. The lomas formations of Coastal Perú: Composition and Biogeographic History. "El Niño in Peru: Biology and Culture Over 10,000 Years". Fieldiana. Botany, New Series 43: 1-9.

Duncan, T. \& M.O. Dillon. 1991. Numerical analysis of the floristic relationships of the lomas of Peru and Chile. American Journal of Botany [abstract] 78: 183.

Hässel de Menéndez, G.G. \& M.F. Rubies. 2009. Catalogue of the
Marchantiophyta and Anthocerotophyta of southern South America. Nova Hedwigia Beiheft 134: 1-672.

Hentschel, J., M. von Konrat, L. Söderström, A. Hagborg, J. Larraín, P. Sukkharak, J. Uribe \& L. Zhang. 2015. Notes on Early Land Plants Today. 72. Infrageneric classification and new combinations, new names, new synonyms in Frullania. Phytotaxa 220(2): 127-142.

Herzog, T. 1954. Zur Bryophytenflora Chiles. Revue Bryologique et Lichénologique 23: 27-99.

IUCN. 2012. IUCN Red List Categories and Criteria: Version 3.1. Second edition. Gland, Switzerland and Cambridge, UK: IUCN. iv + 32pp.

Larraín, J., B. Carter, B. Shaw, J. Hentschel, L.S. Strozier, T. Furuki, J. Heinrichs, B. Crandall-Stotler, J. Engel \& M. VON KonRAT. 2015. The resurrection of Neohattoria Kamim. (Jubulaceae, Marchantiophyta): a six decade systematic conflict resolved through a molecular perspective. PhytoKeys 50: 101-122.

McNeill, J., F.R. Barrie, W.R. Buck, V. Demoulin, W. Greuter, D.L. Hawksworth, P.S. Herendeen, S. Knapp, K. Marhold, J. Prado, W.F. Prud'homme van Reine, G.F. Smith, J.H. Wiersema \& N.J. Turland (Eds. \& Comps.). 2012. International Code of Nomenclature for algae, fungi, and plants (Melbourne Code) adopted by the Eighteenth International Botanical Congress Melbourne, Australia, July 2011. Regnum Vegetabile 154: 1-240.

Rundel, P., M. Dillon, B. Palma, H. Money, S. Gulmon \& J. EHLERINGER. 1991. The Phytogeography and ecology of the coastal Atacama and Peruvian deserts. Aliso 13: 1-50.

Rundel, P., M.O. Dillon \& B. Palma. 1996. Flora and vegetation of Pan de Azucar National Park in The Atacama Desert of Northern Chile. Gayana Botánica 53: 295-315.

Stephani, F. 1911. Frullania. In: Species Hepaticarum 4. George \& Cie, Genève \& Bale, pp. 316-686.

Trinidad, H., E. Huamán-Melo, A. Delgado \& A. Cano. 2012. Flora vascular de las lomas de Villa María y Amancaes, Lima, Perú. Revista Peruana de Biología 19: 149-158.

Uribe MeléndeZ, J. 2008. Monografía de Frullania subgénero Meteoriopsis (Frullaniaceae, Marchantiophyta). Caldasia 30: 49-94.

Von Konrat, M.J. \& J.E. Braggins. 2001. A taxonomic assessment of the initial branching appendages in the liverwort genus Frullania Raddi. Nova Hedwigia 72: 283-310. 